\title{
Minimum Wage Reduce the Low-Skilled Foreign Workers in Malaysian Manufacturing Sector
}

\author{
Sheikh Ahmad Faiz Sheikh Ahmad Tajuddin, Fauziah Abu Hasan, Suriyani Muhamad, \\ Nor Fatimah Che Sulaiman
}

\begin{abstract}
The paper emphasizes on the implementation of minimum wage in Malaysia and subsequent increases of the minimum wage to estimate the minimum wage's effect on the low-skilled foreign workers. High dependency towards the foreign works has been one of the major reasons for the Government to introduce the minimum wage policy in 2012. The study used questionnaire survey and focused on the manufacturing firms in Peninsular Malaysia that are registered with the Federation of Malaysian Manufacturers. We have conducted a panel analysis study covering periods of 2008 to 2017 to analyze the effectiveness of the minimum wage policy in reducing the low-skilled foreign workers. The findings suggested that the employers reduced their low-skilled foreign workers to respond to the implementation and the increase in the minimum wage. The higher statutory wages have caused the firms to reduce their less productive workers. Based on the analysis, we suggest that the companies tend to retain and hire more skills and productive workers in order to cope with the increase in the labour cost. Not only reducing the inflow of foreign workers, the minimum wage policy would have a significant impact towards productivity. Forging ahead with the fourth industrial revolution, productive workers are the key instruments for the firms to remain competitive in the industry as well as to accelerate their productivity and profitability.
\end{abstract}

Keywords: Employment, Foreign Workers, Manufacturing, Minimum Wage

\section{INTRODUCTION}

Manufacturing is one of the most contributor sectors towards the economics of Malaysia. Manufacturing accounted 22.8 percent of the gross domestic product (GDP) in the fourth quarter of 2018 [1]. In term of labour employment, manufacturing has created numerous jobs in the labour market. According to the Labour Force Survey 2018 [2], manufacturing recorded the second largest sector after services with 2.5 million of workers were employed in 2018. However, 20 percent of the number were the foreign workers.

Since 1990s, Malaysia was highly dependent on the foreign

Revised Manuscript Received on October15, 2019

Sheikh Ahmad Faiz Bin Sheikh Ahmad Tajuddin, Faculty of Business, Economics \& Social Development, Universiti Malaysia Terengganu, Terengganu, Malaysia.

Fauziah Binti Abu Hasan, Faculty of Business, Economics \& Social Development, Universiti Malaysia Terengganu, Terengganu, Malaysia.

Suriyani Binti Muhamad, Faculty of Business, Economics \& Social Development, Universiti Malaysia Terengganu, Terengganu, Malaysia.

Nor Fatimah Binti Che Sulaiman, Faculty of Business, Economics \& Social Development, Universiti Malaysia Terengganu, Terengganu, Malaysia. workers. From 400,000 of foreign workers employed in 1990, the number has been tremendously increased to 1.57 million people in 2012 [3]. Cheap labour provided by the low-skilled foreign workers was the most reason why they were hired by most of the employers. Additionally, the low wages have caused lesser participation rate in the low-skilled jobs among the local people. This has caused the employers to hire more foreigners to fill the labour shortage in the low-skilled jobs. However, high inflow of the foreign workers has created several economics and social problems to the country [4]. The employment of the low-skilled foreign workers would deter the productivity enhancement and depressed the overall pay among the other workers. The high dependency towards these workers would also lead to the unemployment of the locals.

To address the issue, the Government has introduced the minimum wage policy in 2012. The minimum wage rates have started with MYR900 for Peninsular Malaysia and MYR800 for East Malaysia. The implementation of minimum wage policy would promote better living standard to the poor paid employees and reduce the dependency on the low-skilled foreign workers [5]. Since it was fully enforced in 2013, the minimum wage rates have been revised twice in 2016 and 2019. The minimum wage has been increased to MYR1000 for Peninsular Malaysia and MYR920 for East Malaysia in 2016. In 2019, the minimum wage has been standardized to MYR1100 for both Peninsular and East Malaysia. However, the Piore's analysis [6] suggested that the inflow of foreign workers cannot be stopped as they are needed to fill the labour shortages in the secondary jobs. More foreign workers also would be interested to join the Malaysian labour market to receive the higher wages. Meanwhile, according to the Household Income, Expenditure and Basic Amenitites Survey 2016 [7], at least MYR2,700 and MYR4,500 of wages are required by a single adult and a couple without child to live in big cities like Kuala Lumpur. These minimum living wages are far higher than the minimum wage rate of MYR1100, thus may not attract the locals to join the low-skilled jobs. The study by Giulietti [8] also has suggested that minimum wage would not negatively affect the immigrants' employment. On the other hand, studies from Edo and Rapoport [9] have shown that the minimum wage policy has been success in reducing the foreign workers. The increase in the labour cost have caused the employers to replace their low-skilled foreign workers with the local workers. 
There were mixed findings from the previous studies on the effect of minimum wage on foreign workers. Hence, the objective of this paper is to analyze the effect of the minimum wage on the low-skilled foreign workers in the manufacturing sector of Malaysia.

\section{METHODOLOGY}

The study aims to estimate the effect of the minimum wage on the low-skilled foreign workers. Apart from the minimum wage and foreign workers, the study has selected the size, profit, age and location of the firm as the controlled variables. The size is the firm's size and is measured by the sales turnover of the firm. The study only considered the medium and large firm. Based on the SME Corporation Classification, a medium manufacturing firm has sales turnover between MYR15 million to MYR50 million while a large manufacturing firm has sales turnover of more than MYR50 million. The profit is the profit that the firm generates in a particular year. The age is the number of years the firm has operated and the location is the firm's location which is divided into for zones namely Klang Valley zone (Kuala Lumpur and Selangor), southern zone (Negeri Sembilan, Melaka and Johor), northern zone (Kedah and Perlis) and eastern zone (Pahang, Terengganu and Kelantan).

The model of the study is as follows:

$\mathrm{FW}_{\text {it }}=\beta_{0}+\beta_{1} \mathrm{MW}_{\text {it }}+\beta_{2} \mathrm{SIZE}_{\text {it }}+\beta_{3}$ PROFIT $_{\text {it }}+\beta_{4} \mathrm{AGE}_{\text {it }}+$ $\beta_{5} \mathrm{LOC}_{\mathrm{it}}+\varepsilon_{\mathrm{it}}$

where

$F W$ is the low-skilled foreign workers,

$M W$ is the minimum wage,

$S I Z E$ is the firm's size,

PROFIT is the firm's profit,

$A G E$ is the number of years the firm has operate,

$L O C$ is the firm's location.

A panel data analysis covering periods of 2008 to 2017 has been conducted in this research. The study used questionnaire survey and focused on the manufacturing industry. 297 manufacturing firms that are registered with the Federation of Malaysian Manufacturers (FMM) were randomly selected to analyze the effectiveness of minimum wage policy in reducing the low-skilled foreign workers.

\section{RESULTS}

The results of the study were divided into two parts namely before minimum wage period (2008-2012) and during minimum wage period (2013-2017). The panel data of 2008-2012 and 2013-2017 were regressed separately in order to identify the effectiveness of the minimum wage in reducing the low-skilled foreign workers. The analysis continued with the diagnostic tests after the linearity and normality check. The diagnostic tests involved the multicollinearity, heteroskedasticity and serial correlation checks. Further analyses were conducted on the pooled ordinary least square (OLS) model, random effects model and fixed effects model. The STATA application was used to run the panel data.

\section{A. Descriptive Statistics Analysis}

Descriptive Statistics summarized the statistics of the variables employed in the model which consist of foreign workers, minimum wage, firm's size, profit, age and location. The descriptions of the variables include the number of observations, mean, median, standard deviation, minimum and maximum value of each data of the variable. Table I and II reported the descriptive statistics for the data period 2008-2012 and 2013-2017.

Table I: Descriptive Statistics Of Determinants And Low-Skilled Foreign Workers For Period Of 2008-2012

\begin{tabular}{|c|c|c|c|c|c|}
\hline $\begin{array}{c}\text { Variabl } \\
\text { e }\end{array}$ & Obs & Mean & $\begin{array}{c}\text { Standard } \\
\text { Deviation }\end{array}$ & Min & Max \\
\hline FW & 1485 & 296.55 & 1793.12 & 2 & 35000 \\
\hline MW & 1485 & 692.20 & 78.43 & 500 & 880 \\
\hline SIZE & 1485 & 1.42 & .49 & 1 & 2 \\
\hline PROFIT & 1485 & 6326612 & $4.32 \mathrm{e}+07$ & 28880 & $1.17 \mathrm{e}+09$ \\
\hline AGE & 1485 & 27.21 & 11.12 & 2 & 81 \\
\hline ZONES & 1485 & 2.36 & 1.29 & 1 & 4 \\
\hline
\end{tabular}

Table II: Descriptive Statistics Of Determinants And Low-Skilled Foreign Workers For Period Of 2013-2017

\begin{tabular}{|c|c|c|c|c|c|}
\hline Variable & Obs & Mean & $\begin{array}{c}\text { Standard } \\
\text { Deviatio } \\
\text { n }\end{array}$ & Min & Max \\
\hline FW & 1485 & 294.35 & 1812.79 & 2 & 36400 \\
\hline MW & 1485 & 940 & 49.01 & 900 & 1000 \\
\hline SIZE & 1485 & 1.42 & .49 & 1 & 2 \\
\hline PROFIT & 1485 & 823210 & $4.92 \mathrm{e}+07$ & 228 & $1.09 \mathrm{e}+09$ \\
\hline AGE & 1485 & 32.21 & 11.12 & 7 & 86 \\
\hline ZONES & 1485 & 2.36 & 1.29 & 1 & 4 \\
\hline
\end{tabular}

Based on Table I, all the variables in the period of 2008-2012 have 1485 observations. The mean for the foreign workers and minimum wage are 296.55 and 692.20. The profit have the highest mean and standard deviation of 6326612 and $4.32 e+07$ respectively. The size have the lowest mean and standard deviation that are 1.42 and 0.49 . The age and zones have the standard deviation of 11.12 and 1.29. In term of maximum and minimum value, profit have the highest maximum value of $1.17 \mathrm{e}+09$ and highest minimum value of 28880. The size have the lowest maximum and minimum value of 2 and 1 respectively. The maximum value for the foreign workers and minimum wage are 35000 and 880 while their minimum value are 2 and 500 . 
Based on Table II, there are also 1485 observations for all the variables in the period of 2013-2017. The mean for the foreign workers and minimum wage are 294.35 and 940 . The profit have the highest mean and standard deviation of 8232106 and $4.92 \mathrm{e}+07$ respectively. The profit also have the highest maximum value of $1.09 \mathrm{e}+09$ and highest minimum value of 2286. The mean, standard deviation, maximum and minimum value for the size and zones in this period are the same as in the period of 2008-2012. The age have maximum and minimum value of 86 and 7 . The maximum value for the foreign workers and minimum wage are 36400 and 1000 while their minimum value are 2 and 900 .

\section{B. Regression Analysis}

Diagnostic checks were conducted to test the problems of multicollinearity, heteroskedasticity and serial correlation. The study also has made further analyses on the pooled OLS model, random effect model and fixed effects model. Breusch-Pagan LM test and Hausman test were conducted to decide whether the pooled OLS, random effect or fixed effect is the appropriate model in the study. As the result of Breusch-Pagan LM test is significant (p-value $<0.05)$ and Hausman test's result is not significant ( $p$-value $>0.05$ ) for the periods of 2008-2012 and 2013-2017, the random effect model is the appropriate model in the study for both periods. The output of the regression results for the period of 2008-2012 and 2013-2017 are based on the random effect model as shown in the Table III and IV.

Table III: Random Effect Results With Dependent Variable: Fw For Period Of 2008-2012

\begin{tabular}{|l|c|c|}
\hline Variable & Coefficients & t-stats \\
\hline & & \\
\hline Mw & 0.326 & $7.75^{* * *}$ \\
\hline Size & -140.8 & $-5.45^{* * *}$ \\
\hline Profit & $8.32 \mathrm{e}-06$ & $8.64 * * *$ \\
\hline Age & 0.617 & 0.55 \\
\hline Zones & 20.61 & $2.09 * *$ \\
\hline Constant & 40.62 & 0.73 \\
\hline $\mathrm{R}^{2}$ & 0.253 & \\
N & 1,457 & 0.0000 \\
Breusch-Pagan LM test & 2294.30 & 0.7394 \\
\hline Hausman test & 9.43 & \\
\hline Multicollinearity (vif) & 1.20 & 0.0000 \\
\hline Heteroskedasticity ( ${ }^{2}-$ stat) & $2.4 \mathrm{e}+07$ & 0.0000 \\
\hline Serial Correlation (F - stat) & 121.899 & \\
\hline
\end{tabular}

$* *$ and $* * *$ indicate the respective $5 \%$ and $1 \%$ significant levels, respectively.

The multicollinearity problem is detected by using variance inflation factor (vif). As the vif is 1.20 which is less than 10 , there is no multicollinearity problem. For the heteroskedasticity check, Modified Wald Statistic is used to detect the problem. Based on the table above, the significant $\mathrm{p}$-value of the $\mathrm{x}^{2}$ stat indicates that there is a heteroskedasticity problem which means the variances are not constant. The serial correlation problem is detected by using the Wooldridge test. The significant p-value of the F-stat indicates that there is a serial correlation problem. As the diagnostic checks detected the heteroskedasticity and serial

correlation problems for the period of 2008-2012, the standard errors in the model are estimated based on Rogers [10] clustered at firm level. Clustering at firm level results to a robust estimator to cross-sectional heteroskedasticity and within panel correlation.

Based on the random effect model in the table above, the findings suggested that the minimum wage and foreign workers have significant positive relationship before the minimum wage policy was implemented. An increase of minimum wage by MYR10 would increase the foreign workers by 3 people. With no minimum wage policy been implemented before 2013, the firms have mostly employed the cheap foreign workers in the low-skilled jobs.

There are five controlled variables in the study and the findings suggested that all the controlled variables (size, profit and zones) are significant except age. The negative relationship between size and foreign workers indicates that large firms would have more foreign workers as compared to the small firms. Meanwhile, profit has a positive relationship with the foreign workers. High profit and large firms would require more low-pay foreign workers as the firms require more manpower in the secondary jobs.

\section{Table IV: Random Effect Results With Dependent Variable: Fw For Period Of 2013-2017}

\begin{tabular}{|c|c|c|}
\hline Variable & Coefficients & t-stats \\
\hline Mw & -0.207 & $-4.68 * * *$ \\
\hline Size & -179.8 & $-6.05 * * *$ \\
\hline Profit & $8.74 \mathrm{e}-06$ & $9.70 * * *$ \\
\hline Age & -4.100 & $-3.51 * * *$ \\
\hline Zones & 3.256 & 0.29 \\
\hline Constant & 698.1 & 11.10 \\
\hline $\mathrm{R}^{2}$ & 0.212 & \\
\hline $\mathrm{N}$ & 1,465 & \\
\hline Breusch-Pagan Lm test & 2537.76 & 0.0000 \\
\hline Hausman test & 3.67 & 0.0553 \\
\hline Multicollinearity (vif) & 1.06 & \\
\hline Heteroskedasticity $\left(\mathrm{x}^{2}-\mathrm{stat}\right)$ & $3.4 \mathrm{e}+07$ & 0.0000 \\
\hline Serial Correlation (F - stat) & 61.744 & 0.0000 \\
\hline
\end{tabular}

$* *$ and $* * *$ indicate the respective $5 \%$ and $1 \%$ significant levels, respectively.

The diagnostic checks for the period of 2013-2017 also has indicate the presence of heteroskedasticity and serial correlation problems. Hence, the standard errors in the model are clustered at firm level to rectify the problems.

Based on the random effect model in the table above, the findings reveal that the effect of minimum wage on the foreign workers is significant at ( $p$-value $<0.01$ ) with a negative relationship. After the minimum wage policy has been implemented, an increase of minimum wage by MYR10 would reduce the foreign workers 2 people. The increase in the labour cost have caused the firms to reduce their low-skilled foreign workers. The low-skilled foreign workers have been replaced by the locals and more productive workers. 


\section{DISCUSSION}

The findings suggested that the cheap labour have caused the employers to hire more foreign workers during the period of 2008-2012. As there is no legal policy that require the employers to pay a specific minimum salary to their workers, the employers have chosen to hire the cheap foreign workers to fill the labour shortage in the low-skilled jobs. The high employment of the foreign workers in the low pay jobs is associated with the firm's objective to cut cost and maximize profit [11].

However, the implementation of the minimum wage policy in 2013 has caused a decreasing number of foreign workers in the manufacturing sector. As the employers have to incur higher labour cost, they have reduced their low-skilled foreign workers and focused on the productive employees. The productive employees would diverge the labour costs' increase and contribute to a better performance of the firm [12]. The data from the Ministry of Home Affairs [13] also have shown that the number of foreign workers has decreased after the minimum wage policy was implemented in 2013.

Additionally, the data collected has shown that the participation of the local workers in the low-skilled jobs has increased since the implementation of the minimum wage policy. With higher benefits and salary, the local workers are more motivated to work in the secondary jobs. A study that has been conducted in Malaysia [14] has suggested that the financial compensation including salaries and bonuses would increase the employee's commitment towards an organization.

The increasing standard and requirements by the Ministry of Home Affairs to employ the foreign workers together with the higher labour cost due to the minimum wage policy have caused the employers to reduce the foreign workers and increase the local workers in the low-skilled jobs.

Nevertheless, the firms have to come out with the initiatives to make sure the local workers are productive and can contribute to the firm's performance. Forging ahead with the fourth industrial revolution, having productive workers through good trainings and business plans are the key instruments for the firms to remain competitive in the industry.

\section{CONCLUSION}

Low-skilled foreign workers were highly employed in the manufacturing sector. Low participation rate from the local people in the low-skilled jobs due to the cheap salary has forced the employers to hire the foreign workers in order to fill the labour shortage. Hence, high dependency of the employers towards the foreign workers and the low salary received by the low-skilled workers has caused the Government to introduce the minimum wage policy in 2012. The implementation of the minimum wage policy has made impacts on the number of local and foreign workers. The study suggested that the minimum wage policy has managed to reduce the dependency of the manufacturing firms on the low-skilled foreign workers. With higher labour cost need to be incur, the employers have replaced their low-skilled foreign workers with more productive workers. The higher minimum wage would also attract more local workers to join the low-skilled jobs. With the increase wages, the workers are more motivated to work and would cause higher productivity to the firms.

\section{REFERENCES}

1. Department of Statistics Malaysia, "Malaysia economic performance fourth quarter 2018," Department of Statistics Malaysia, 2018. Available:

https://www.dosm.gov.my/v1/index.php?r=column/pdfPrev\&id=aHRy dmZMSmtNL01TbW43SjVOSIZkQT09. [Accessed July 25, 2019].

2. Department of Statistics Malaysia, "Labour force survey time series statistics," Department of Statistics Malaysia, 2018. Available: https://www.dosm.gov.my/v1/uploads/files/3_Time\%20Series/LFS_19 82-2018/12. TABLE_12.pdf. [Accessed July 20, 2019].

3. Ministry of Home Affairs Malaysia, "Official documents, national publication 2016," Ministry of Home Affairs Malaysia, 2017. Available:

https://www.data.gov.my/data/ms_MY/dataset/jumlah-pekerja-asing-pl ks-aktif-mengikut-sektor. [Accessed July 23, 2019].

4. A. J. Wei, A. Murugasu, C. Y. Wei, "Low-skilled foreign workers' distortions to the economy," 2018, pp. 1-12.

5. V. Senasi, S. Khalil, "Implementation of minimum wage policy in Malaysia: manufacturing employers' perceptions of training provision and fringe benefits," International Journal of Humanities and Social Science, vol. 15 (12), 2015, pp. 87-94.

6. M. J. Piore. Birds of passage: migrant labour and industrial societies. New York: Cambridge University Press; 1979.

7. Department of Statistics Malaysia. Report of Household Income and Basic Amenities Survey 2016. Department of Statistics Malaysia; 2017. Available: https://www.dosm.gov.my/v1/index.php?r=column/pdfPrev \&id=RUZ5REwveU1ra1hGL21JWV1PRmU2Zz09. [Accessed July 22, 2019].

8. C. Giulietti, "Do minimum wages induce immigration?" IZA World of Labor, May 2015.

9. A. Edo, H. Rapoport, "Minimum wages and the labor market effects of immigration," Labour Economics, July 2019, p. 101753.

10. W. Rogers, "Regression standard errors in clustered samples," Stata Technical Bulletin, vol. 13, 1993, pp. 19-23

11. E. Appelbaum, J. Schmitt, "Low-wage work in high-income countries: labor-market institutions and business strategy in the US and Europe," Human Relations, vol. 62 (12), 2009, pp. 1907-1934.

12. P. Turnbull, S. Weston, "The British port transport industry part 2. Employment, working practices and productivity," Maritime Policy and Management, vol. 20 (3), 1993, pp. 181-195.

13. Ministry of Home Affairs Malaysia, "Official documents, national publication 2018," Ministry of Home Affairs Malaysia, 2018 Available: http://www.moha.gov.my/index.php/en/data-terbuka. [Accessed July 20, 2019].

14. L. B. Kee, R. Ahmad, S. M. Abdullah, "Relationship between financial compensation and organizational commitment among Malaysia bank workers," Asian Business Research, vol. 1 (1), 2016, p. 75. 


\section{AUTHORS PROFILE}

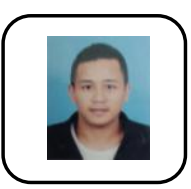

Sheikh Ahmad Faiz Bin Sheikh Ahmad Tajuddin is currently a $\mathrm{PhD}$ student at Universiti Malaysia Terengganu. He has a Master of Commerce from University of Queensland and Bachelor of Economics from International Islamic University of Malaysia. His research area is Economic Development, focusing on labour economics and policies.

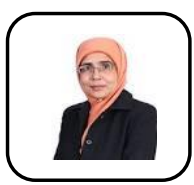

Fauziah Binti Abu Hasan is a Professor at Universiti Malaysia Terengganu. She holds a doctorate in international and development economics from Florida State University. She obtained her masters and undergraduate degree from Western Michigan University in statistics and economics. Her research interests include international and development economics and issues in higher learning education. She started working as a lecturer in 1985 and has served the university in various capacities such as being the head of department, deputy dean, head of corporate planning, director of quality assurance, dean of faculty and assistant vice-chancellor. In terms of publications, she has authored various book, book chapters, papers and articles in her field of research.

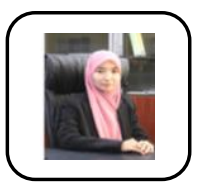

Suriyani Binti Muhamad is an Associate Professor at Universiti Malaysia Terennganu. She completed her PhD in Economics from University of Manchester. She has a Master of Science from London School of Economics and Bachelor of Economics from University of Malaya. Her research area focuses on Economic Development and her research interests include health economics, labour and gender, specifically on woman issues. To date, she has published more than 30 articles in SCOPUS and ISI journals. She also undertakes and involved in related research grants, locally and international.

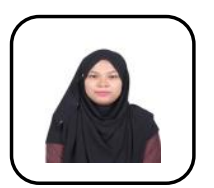

Nor Fatimah Binti Che Sulaiman is a lecturer a Universiti Malaysia Terengganu. She completed her PhD in Economics from Universiti Kebangsaan Malaysia. She has a Master of Science (Economics) from UMT and Bachelor of Economics from Yokohama National University. Her research area focuses on economic development and her research interests include human and community development, innovation and income distribution. To date, she has 5 journal publications indexed in SCOPUS, ECSI and ERA. 